\title{
Contribution of the U.S. Office of Education in the Field of College and University Library Statistics: Present and Potential'
}

Mr. Dunbar is chief, Service to Libraries Section, and Dr. Mishoff is specialist, College and Research Libraries, Library Service Division, U.S. Office of Education.

I HIS Geography of Reading, Louis R. Wilson writes: "One of the limitations of librarianship today, is that it lacks a fundamental body of data ... which can be compared exactly and applied to the solution of problems by which it is beset." Although this statement was made a decade ago, it is still true today.

The purpose of this paper is to take stock of what is being done to remedy this lack of basic statistics, which are needed in the practical operation of college and university libraries and in planning programs for further progress. In order to show the contribution of one agency, we are going to outline the present program of the U. S. Office of Education in the field of college and university library statistics. Since the situation in the federal government is never static-owing to certain factors which will be described later-we shall be somewhat venturesome and discuss also our "potential" program.

At the risk of stating the obvious and of being somewhat academic, we are making

1 Paper presented by Mr. Dunbar at the meeting of the A.C.R.L., Chicago, Jan. 3o, 1948. at the outset some general observations on the subject of library statistics in institutions of higher education:

I. Statistics are compiled not for the benefit of the collecting agency, but for the use of practitioners of college and university librarianship. They are also for the use of those who wish to measure library progress, note trends, and set goals in relation to the educational program.

2. Statistics cost money, and their cost must be justified. They cost the reporting institutions which fill out the forms; they cost the collecting agency in checking the returns, in clearing up any discrepancies, in making the compilations, in attempting at least some interpretations of the data, and in getting the material printed and distributed.

3. Statistics can be collected only if li-:braries keep them and are willing to report them.

4. Statistics buried in report forms and files might as well, in many cases, never have been collected. True, they have a potential use. but often that is not high. Provision must be made for getting statistics printed, multilithed, or punched on cards.

5. Statistics to be useful to the practical administrator must be available promptly and be comparable over a period of years.

6. Statistics must be collected according to a carefully planned program. An example of such planning may be seen in the "Plan for the Collection and Dissemination of Library Statistics," prepared in tentative form by the A.L.A. Committee on Statistics and presented by its chairman, G. Flint Purdy, to a con- 
ference on statistics held at the Office of Education March 4-5, 1946. The plan provided for: (a) comprehensive research statistics to be collected every five or six years, (b) annual statistics of library trends for a representative sample of libraries, (c) annual statistics of "good" libraries to be used in internal administrative evaluation and campaigns with local authorities, and (d) popular presentations of major library statistics for the purpose of promoting public understanding of libraries.

The present program of the U. S. Office of Education in the field of college and university library statistics calls for at least four major activities, three of which fall primarily within the province of the Service to Libraries Section, and the Research and Statistical Service.

I. Nationwide survey. This involves a comprehensive collection and publication of eollege and university library statistics once every four years on as uniform a pattern as possible. This means collecting data, if possible, from each of the I 700 institutions of higher education in the United States and its outlying territories. The office will obtain and publish statistics from individual colleges and universities on such items as:

Number of volumes added during the year

Number of volumes at end of the year

Circulation: Home use

Circulation: Reserved books

Number of hours open per week (central library)

Staff: Number of professional workers

Staff: Number of subprofessional workers

Staff: Number of clerical workers

Number of students: Undergraduates

Number of students: Graduates

Expenditures for library staff salaries

Expenditures for books and periodicals

Expenditures for binding

Expenditures for audio-visual materials

Expenditures for other purposes, excluding building maintenance.

In addition, there will be available for possible printing in the detailed tables, statistics on such items as:
Holdings of materials other than print

Use of such materials insofar as the libraries keep such records

Number of volumes acquired by purchase

Number of volumes acquired by other means than purchase

Number of periodicals currently received

Number of newspapers currently received

Number of interlibrary loans (book materials), both borrowed and lent

Interlibrary transactions in the field of photostats, microfilms, etc.

Breakdown of the staff by positions.

To make all the items just named available through printing, it will be necessary for the office either to have a greatly increased printing budget or else to experience a marked decline in the cost of printing.

As in the College and University Library Statistics, 1939-40, it is planned to have the forthcoming publications carry national summaries, state totals, comparative totals, and distribution tables for the significant items.

Work is now proceeding on the nationwide collection of college and university library statistics for the fiscal year which ended June 30, 1947, or any other time during 1947. The data are being collected on a form designed by the Research and Statistical Service of the Office of Education to facilitate the use of punched cards and machine tabulations. The new form follows closely the one employed for the collection of 1940 statistics, the chief change being the elimination of some little-used items. The libraries will be coded so that similar institutions can be grouped readily for various statistical computations. This machine tabulation should also aid the prompt issuance of the preliminary releases.

2. Preliminary releases. When comprehensive collections of college and university library statistics are made, as is the case this year, our program calls also for the issuance of preliminary releases of uninter- 
preted data from selected groups of institutions. This plan was followed successfully in the case of the 1945 public library statistics. Multilithed circulars for certain population groups were ready for mailing within six weeks after the returns were in. We propose to render a similar service to college and university librarians.

3. Salary study. In our program plans for this year, we have included a study of college and university library salaries, to be undertaken early in I948. This project should yield data similar to those on college faculties for 1939-40, which were published by the Office of Education in its "Circular No. i96." Our library study, as planned, will result in salary distribution tables for specific kinds and grades of positions in selected groups of institutions.

The study should produce such facts as these: In a certain group of universities located in a certain region, Io chief catalog librarians fall within the $\$ 3600-\$ 3999$ annual salary bracket; 7 within the $\$ 4000-$ $\$ 4399$ bracket; 5 within the $\$ 4400$ to $\$ 4799$ bracket; etc. Similar information would be ascertained for the directors, for assistant directors, for chief circulation librarians, for professional assistants of different grades, etc.

These tabulations will not list, however, specific salaries at specific institutions. They will not show what the director of libraries at university " $X$ " receives for an annual salary. Nor will they show that the library of university " $X$ " has 6 department heads who receive annual salaries ranging from $\$ 3400$ to $\$ 5500$, but we should be able to furnish some sound figures for the study of the library salary situation in the college and university library field.

4. Division of Higher Education compilations. The Division of Higher Education of the Office of Education has a program in the field of statistics which is of sig- nificance to college and university librarians. There are the biennial surveys of education which contain both detailed and summary tables of statistics on colleges and universities. Of late years, total library expenditures of colleges and universities have been included with other financial data of these institutions. Formerly, the total number of volumes in college and university libraries was given also, but this information has been omitted since detailed reports have been a major responsibility of the Service to Libraries Section. In addition, there are special studies on salaries of college faculties, enrolments, Negro colleges, and various others. At the present time, the statistical program of the Division of Higher Education is being self-examined critically to make its usefulness to college and university administrators still greater.

\section{Potential Program}

The foregoing is an account of our present program in the field of college and university library statistics. What about the "potential program?" Here we run into conflicting forces. There are, for example:

I. The expressed requests for library statistics made by administrators, research workers, planners, and others.

2. The efforts of the Service to Libraries Section and Research and Statistical Service to meet these requests as far as possible.

3. The general program of the Office of Education conditioned as it is by its basic law and by available funds.

4. The Bureau of the Budget which exercises control both over recommended appropriations and over question blanks sent to respondents.

5. The Congress of the United States which is the ultimate, determining factor in any federal government activity.

A few words are in order about these forces which have just been enumerated. The requests and recommendations of the librarians are naturally powerful influences. 
Some wish only a few items, and the simpler the form, the better; others have recommended that some 300 be collected. But there are also other factors with which to reckon.

The Service to Libraries Section endeavors to be responsive to these expressed requests but it has to work within the framework of the general statistical program of the Office of Education. The Office of Education operates under an 1867 Act of Congress which required it to collect "such statistics and facts as shall show the condition and progress of education in the several States and territories." Ever since I 870, the Office of Education has been doing that, conditioned by the funds made available by the Congress for staff and printing. Recently, the office has been scrutinizing its whole statistical program and has had the benefit of the advice of expert conferees. ${ }^{2}$

The Bureau of the Budget has much to say about the extent of the statistical activity of a federal agency. As previously mentioned, it passes on the budget request which the Office of Education submits through the Federal Security Agency. It is the Bureau of the Budget which finally submits the President's budget to the Congress. Furthermore, the approval of the Bureau of the Budget must be obtained before a report form can be used in obtaining data from more than 9 respondents. The bureau examines these proposed blanks closely. It questions the significance and usefulness of items in the public interest; it seeks to guard taxpayers against wasteful government projects; it endeavors to protect respondents from having questionnaires which are too long, too complicated, or too frequent. This action is not just an optional exercise of authority; it is required by law.

2 Proposals Relating to the Statistical Function of the U.S. Office of Education. U.S. Office Bulletin 1946, No. 2. Washington, U.S. Government Printing Office, 1946.
The Congress of the United States was described earlier as a determining factor in the statistical activities of federal agencies. Ample evidence of this may be found in the hearings before the House Subcommittee on Appropriations which was considering the 1945 appropriations for the Office of Education. ${ }^{3}$ There, in five printed pages, you will find discussed in vigorous fashion the question of library statistics, especially college and university library statistics.

For instance, a member of the subcommittee, after examining College and University Library Statistics, I939-40, asked: "Who would make use of any such statistics as are contained in this volume?"

The Acting Commissioner of Education explained to the subcommittee how the data would be used not only by college and university librarians, but also by college and university presidents.

The same Congressman then pointed to the detailed statistics in the bulletin and observed:

I just wonder whether we are engaged in a program in which the public has a great significant interest in statistics of that character. I confess, on the face of it, it does not impress me very strongly. You have a lot of statistics as to how many books there are in all the libraries of the country, and that sort of thing.

At this point the Acting Commissioner inserted in the record a letter from William Hugh Carlson, who, as chairman of a postwar committee, had written to ask for more statistics, and also to express his appreciation of the useful data contained in College and University Library Statistics, 1939-40.

The Congressman nevertheless continued:

Of course it is a fine thing that we have got

${ }^{3}$ Hearings beforc the Subcommittee of the Committee on Appropriations. House of Representatives. Seventy-eighth Congress. Second Session on the Department of Labor-Federal Security Agency Appropriation Bill for 1945. Part 3, p. $156-60$. 
government agencies staffed to furnish all this information and material. Perhaps it would be possible for someone, some library head, who had a particular problem in mind and wanted to. find out what his neighbor was doing, to write a few letters himself and get those facts, without the federal government publishing a great mass of detailed statistical information which I cannot conceive would be of any value to anybody.

The Office of Education witnesses pointed out the difficulties involved in the preceding suggestions, but the Congressman came back to the question of the value of these statistics to the public. Other Congressmen then joined in with questions about the arrangement of the data, and cost.

Our "potential" statistical program is thus impinged upon by some powerful forces. With these in mind, let us consider the direction in which we are moving in the field of library statistics in cooperation with the Research and Statistical Service of the Office of Education:

I. A quadrennial collection and publication of the major significant data from all college and university libraries in the United States and its territories. The number of significant items to be reported upon would be at least 28 , not including certain sub-items, needed for auditing purposes, or for derived statistics.

2. An annual collection and publication of the most essential statistics from representative samples of college and university libraries. The number of items to be reported on would be probably 6 to 8 . Emphasis would be on prompt availability of the data to the profession.

3. An annual or biennial salary study based on data received from representative samples. The published results would not contain specific salaries paid to specific persons at specific institutions, but rather the salaries, distributed by salary brackets, paid in more or less homogeneous groups of college libraries, for specific classes of positions.
It might contain, for example, the number of salaries in a series of brackets being paid to beginning professional catalogers in the libraries of the medium-sized liberal arts colleges of the Midwest. The groupings might be by: (a) type of control of the institution; (b) by type of institution; (c) by kinds of students served; and (d) possibly, by accredited status. These groupings would be accompanied by: (a) national totals, and (b) regional totals either by political units or accrediting agencies.

4. Special studies involving the collection of data on specific phases of library administration from a limited number of different types of institutions willing to cooperate in keeping special records such as:

a. Detailed statistics of library use

b. Detailed statistics on sources of additions to book stock

c. Detailed statistics on interlibrary loans

d. Detailed statistics on cataloging operations in college libraries

e. Detailed statistics on the delivery and nondelivery of items requested at the loan desk

f. Sources of income of college and university libraries

g. Cost studies of library operations.

Please note that the preceding statistical studies are, in the main, potential and not actual. How many of these can be put into effect depends upon the various forces bearing down upon the statistical program.

Since data gathered by the Division of Higher Education have significance for college and university librarians, we should take into account also the proposed statistical program of that unit of the Office of Education. It is proposed, for example, to collect and publish annually general enrolment statistics for the autumn quarter or semester, and for the summer session. Biennially and quadrennially, more detailed enrolment figures would be așked for. For instance, in the quadrennial collection, the number of students preparing for various 
professional fields would be ascertained, if possible, and the number enrolled in specific subjects.

The Division of Higher Education of the Office of Education is giving consideration to a plan for obtaining reports on the college and university staff at annual, biennial, and quadrennial intervals. Annually, for example, the number of college level instructors would be asked for. Biennially, the number of academic staff would be enumerated in detail by type of activity (instruction, research, etc.). A biennial salary survey is being considered covering such items as salary, academic rank, extent of annual service, etc. Quadrennially, a similar study might cover nonacademic staff members. At a similar interval, the qualifications of the instructional staff (especially as to degrees) might be studied.

The Division of Higher Education also proposes to call for annual and biennial reports on the finances of colleges and universities. Biennially, the schedule provides for data on additions to capital funds, current income by source, expenditures by function, and fund and plant values. On a sampling basis, it is proposed to ask annually in the spring for statistics giving the economic outlook for higher education, covering estimates of income for current educational and general purposes by sources. 'The volume of estimated change in income and expenditures for the coming academic year might be sought. Specific estimates in expenditures for libraries and faculty salaries might be included here. In this report, too, any estimated change in student enrolment could be asked for.

Finally, every four years, the Office of Education would like to study the plant facilities of colleges and universities throughout the nation, specifically as to floor space devoted to various types of use, dates and types of construction, the existing capacity for the accommodation of students (includ- ing library reading rooms and study halls, classrooms, laboratories, etc.) and the provision for faculty offices.

An authoritative and detailed analysis of the present and potential college and university statistical program of the Office of Education, may be found in the published statement of Dr. John Dale Russell, director of the Division of Higher Education, to the American Association of Collegiate Registrars. ${ }^{4}$

The Service to Libraries Section of the U. S. Office of Education aims to carry on a statistical program which will build up that "fundamental body of data which can be applied to the solution of problems by which librarianship is beset." We, therefore, make the following recommendations:

I. We need an official body, representative of the profession, to which we can turn, as occasion may arise, for authoritative advice and guidance in planning statistical activities and projects in the field of college and university librarianship to be undertaken by the Office of Education.

2. We need an authoritative professional source for library terminology and definitions which the Office of Education can use with assurance that it represents the best current thought and practice on college and university librarianship.

3. We need to explore the possibility of cooperative arrangements with state library agencies which are charged by state law with the collection of college and university library statistics.

4. We need a continued understanding of the mutual responsibilities and limitations of a federal agency on the one hand and professional organizations on the other. The government is especially fitted for certain statistical activities; a nongovernment organization, for others.

5. We need a clear recognition of the fact that a material expansion of library statistics and related facts in the Office of Education can be justified only by the demonstrated needs of our professional and lay constituency.

\footnotetext{
"The Collection of Statistics on College Enrollments." College and University 23: 16-31, October 1947.
} 